\title{
Role of Stream on the Occupational Aspirations and Career Maturity of the Students of Senior Secondary
}

\author{
Lilu Ram Jakhar \\ Govt College of Education, Sector 20-D, Chandigarh-160020, India
}

"Email: leejakhar@gmail.com

\section{ARTICLE INFORMATION}

Received: November 08, 2018

Revised: January 15, 2019

Accepted: February 15, 2019

Published online: March 04, 2019

\section{Keywords:}

Career Maturity, Occupational Aspiration,

Correlation, Adolescents, Stream

\begin{abstract}
The adolescents' occupational aspirations is affected by various factors such as intelligence, emotional stability, growth and development, peer group interest, family background, social and economic life and the cognitive maturity to select a career according to the one's interest and needs. Adolescents' career maturity is influenced by the attitude and the competencies of the individual. The study focused on finding out the relation between occupational aspirations and career maturity of the senior secondary school students according to their streams of study. The results of the study indicated no significant correlation between the occupational aspirations and career maturity of the arts stream senior secondary school students and it also shows no significant correlation between the occupational aspirations and career maturity of the Science stream students of senior secondary classes.
\end{abstract}

\section{Introduction}

The concept of career maturity originated from the term vocational maturity and it refers to the person's degree of readiness to choose, prepare well and plan for the future vocation. Career maturity has been considered as a prerequisite essential ability to make a right choice of the occupation and fulfill career related needs. It is assumed that maturity development occurs along a continuum of thinking and cognition; higher the maturity of the person, the greater is the likelihood that person is able to cope with developmental tasks at various stages of the professional career. Therefore, the career maturity involves forming interests and developing attitude in making consistent and competent to make choices towards the career. But making right career choices is quite a difficult task. Career choice has to be based on good and realistic decisions taken at a proper age. If the right career choice is made at an appropriate stage then the rest of life sails smoothly thereby providing an individual a personal gratification, contentment and fulfillment of life.

The thoughts, feelings, fantasies and goals of an individual regarding the areas of work affecting the motivation as well as the decision making for the occupational choice and subsequent involvement in occupation is basically termed as occupational aspirations. Occupational aspirations are important for understanding an individuals' self-concept, behavior related to the career and attitude, assessment of the effect of social factors on the available opportunities and hence the future educational aspiration and choices related to the career and their extent of attainment. Hoppe (1930) opined that "the level of aspiration represents a person's expectations, goal, claims, or his future achievement in a given task". Rojewski (2005) opined that "occupational aspirations refers to an individual's expressed career related goals or choices". Johnson (1995) defined "the occupational aspirations as expressions of occupational goals, leading several authors to regard them as important career motivational variables, proving to be predictive of later career attainment levels". Van Tuijl \& Van der Molen (2016) explored the role of study choice on the career decisions of the young adults and observed that carried choices have roots in earlier childhood expectations. The authors observed that aspirations are important in making the study choice and hence career development 
of the young children and the factors affecting the carries development are knowledge of subject, affective values, the beliefs and self-efficacy building among the students. Gutman and Schoon (2018) conducted a study titled "Aiming high, aiming low, not knowing where to go: Career aspirations and later outcomes of adolescents with special educational needs" to investigate the role of the early career aspirations of adolescents in predicting the educational achievement and the occupational outcomes of the adolescents. The author investigated the difference in career aspirations of the children having special educational needs and those with normal educational behaviour. The study predicted the higher later educational and employment outcomes among students having high career aspirations at age 14 as compared to the age of 16 to 20 for adolescents with special educational in comparison to those without special education needs. Thus there is need to identify the career aspirations in early adolescence and adopt suitable strategies to encourage them to attain their career potential.

Studies have shown that the career choices and achievements are affected by the occupational aspirations of adolescents (Wu, 2012). Davis (2013) found positive and significant correlation between the academic performance and educational requirement for the specific occupations before attending the school and after entering into the high school stage. The future occupational aspirations are affected by the academic self-concept at high school stage (Guo et al. 2015). Malik (2015) found that there is significant relationship between the performance in academics and attitude towards their school and their later occupational choice. Andleeb and Ansari (2016) carried out a detailed comparative study to explore the correlation between career maturity of the adolescents and occupational aspirations and found weak and negative correlation between occupational aspirations of the adolescents and their career maturity. Therefore the researches focusing on the occupational aspiration, and career maturity of students reveals that the career choices of the students are influenced by many factors social as well as psychological, and the academic achievement.

\section{The Rationale of the Study}

Senior secondary stage is the stage to make career planning and think of future career options. The career choices are basically linked to their occupational aspirations which greatly influence the personality of an individual, particularly the senior secondary students. The career decisions at this stage affect the subsequent educational and vocational choices. Career maturity of the secondary students comes through exposure and academic awareness in different fields. The students opt for different streams depending upon their maturity of career planning. Career choice has to be based on good and realistic decisions taken at an appropriate age, the right career choice made at an appropriate stage make the rest of life smooth and contented. Studies have revealed that the career choices and achievements are significantly influenced by the occupational aspirations of adolescents (Wu, 2012). Due to parental pressure students choose a stream of study to go to occupations such as doctors, engineer irrespective of their requisite capabilities, which causes a lot of frustration and dissatisfaction among the students. Therefore, the study undertaken was planned to explore whether occupational aspirations, in any way of the senior secondary school students of various streams is linked to their career maturity.

\section{The Objectives of the Study}

1. To find out the relationship between occupational aspirations of arts stream senior secondary students and their career maturity

2. To find out the relationship between occupational aspirations of science stream secondary students and their career maturity

\section{The Hypotheses of the Study}

The null hypotheses planned and formulated as under were tested in this study:

1. There exist no significant correlation between occupational aspirations and career maturity of the arts stream senior secondary students.

2. There exist no significant correlation between occupational aspirations and career maturity of the of science stream secondary student.

\section{The Design and Procedure of the Study}

The main focus of this present study was to find the relation between occupational aspiration and career maturity of the senior secondary school adolescents. 
The present study was carried out by using descriptive survey method. Further, the study was delimited to two variables viz. career maturity and occupational aspirations. The sample taken for the study consisted of 200 students of senior secondary classes of different government schools in Chandigarh from Arts as well as Science streams divided equally. The standardized tools used for the research were the Career Maturity Inventory (CMI) by John O' Crites (1978) and its Indian adaptation by Nirmala Gupta (1989) and Occupational Aspiration Scale (OAS) by J.S. Grewal (1973). The tools were administered to the target groups as per the instructions mentioned in their respective manuals.

\section{The Analysis of Data and the Interpretation of Results}

The data so collected through the specified tools was analysed by employing descriptive techniques and using the inferential statistics. The results so obtained were thus interpreted accordingly. The data concerning the occupational aspiration of the senior school students as well as their career maturity of the total sample was analysed and the coefficient of correlation computed and is depicted in Table 1 below.

Table 1: Correlation between Occupational Aspiration of the Arts stream students and their Career Maturity.

\begin{tabular}{|c|c|c|c|c|}
\hline Variables & $\mathbf{N}$ & Mean & r - value & $\begin{array}{l}\text { Level of } \\
\text { significance }\end{array}$ \\
\hline Career maturity & 100 & 56.49 & \multirow{2}{*}{0.15} & \multirow{2}{*}{$\begin{array}{l}\text { Not } \\
\text { Significant }\end{array}$} \\
\hline Occupational Aspirations & 100 & 47.82 & & \\
\hline
\end{tabular}

(Critical values of $\mathrm{r}=0.196$ at 0.05 and 0.254 at 0.01 level, $\mathrm{df}=99$ )

From the above Table no. 1, it is quite clear that the mean score of the career maturity of the total sample of the arts stream students is $\mathbf{5 6 . 4 9}$ and the mean score of the occupational aspiration of Arts stream students is 47.82 , the coefficient of correlation between career maturity and occupational aspiration is 0.15 , which is even quite lesser than that of the table value of 0.196 against the 0.05 level of significance testing. Thus, the results indicate that correlation between occupational aspiration of the students and the career maturity of the
Arts stream senior secondary students of the schools is not significant at 0.05 level of significance.

Table 2: Correlation between Occupational Aspiration of the Science stream students and their Career Maturity.

\begin{tabular}{|c|c|c|c|c|}
\hline Variables & $\mathbf{N}$ & Mean & r-value & $\begin{array}{l}\text { Level of } \\
\text { significance }\end{array}$ \\
\hline Career maturity & 100 & 62.97 & \multirow{2}{*}{0.02} & \multirow{2}{*}{$\begin{array}{c}\text { Not } \\
\text { significant }\end{array}$} \\
\hline $\begin{array}{l}\text { Occupational } \\
\text { Aspirations }\end{array}$ & 100 & 52.96 & & \\
\hline
\end{tabular}

From the above Table no. 2, it is quite clear that the mean score of the career maturity is found to be 62.97 and the mean of occupational aspiration is 52.96, the coefficient of correlation between career maturity and occupational aspiration is 0.02 , which is even quite lesser than that of the table value of 0.196 against the 0.05 level of significance testing. Thus, the results indicate the correlation between occupational aspiration of the students and the career maturity of the Science stream senior secondary students of the schools is not significant at 0.05 level of significance testing.

There are limitations with regards to the sample size and the population and the study can be replicated to the larger population covering different streams of study instead of only two streams offering wide spectrum of subject choices. The important implication of the study is the predicted value in the rightful career options for the youth. The study also had limited scope in the sample distribution and the same could be used to cover wider area with different cultural and social background of the student population.

\section{Conclusions}

Analysis and interpretation of results of the study reveals that: i) there is a variation in career maturity of the Arts and Science stream senior secondary students, ii) there is also variation in occupational aspiration of the Arts and Science stream senior secondary students, iii) there exist not much significant correlation between occupational aspiration of Arts stream senior secondary students of school and their career maturity, iv) there exist not much significant correlation between 
occupational aspiration of Science stream senior secondary students of school and their career maturity. The results of the study were supported by the findings of the Andleeb \& Ansari (2016). The study suggests that the scheme of study have no significant bearing on the relationship of occupational aspirations of the students of senior secondary and their career maturity.

\section{References}

Andleeb \& Ansari, M. (2016). A comparative study of occupational aspiration and career maturity of senior secondary school students in relation to gender. International Education and Research Journal, 2(7), 79-81.

Armstrong, P. I., \& Crombie, G. (2000). Compromises in adolescents' occupational aspirations and expectations from Grades 8 to 10. Journal of Vocational Behavior, 56, 82-98. https://doi.org/10.1006/jvbe.1999.1709

Crites, J. O. (1978). Career Maturity Inventory. Monterey, Califf: CTB, McGraw Hill.

Davis A., (2013). Pediatrician or professional athlete? Gender, ethnicity, and occupational aspirations of urban adolescents. Journal of Education, 18(2), $141-152$. https://doi.org/10.1080/10824669.2013.797883

Grewal, J. S. (1973). Manual of Occupational Aspiration Scale. National Psychological Corporation: Agra.

Guo J., Marsh H. W., Morin A. J. S., Parker P. D. \& Kaur G., (2015). Directionality of the Associations of High School Expectancy-Value, Aspirations, and Attainment: A Longitudinal Study. American Educational Research Journal, 52(2), 371-402. https://doi.org/10.3102/0002831214565786

Gutman, L. M., Schoon, I., \& Sabates, R. (2012). Uncertain aspirations for continuing in education: Antecedents and associated outcomes. Developmental Psychology, 48, 1707-1718. https://doi.org/10.1037/a0026547

Gutman, L. M., \& Schoon, I. (2018). Aiming high, aiming low, not knowing where to go: Career aspirations and later outcomes of adolescents with special educational needs. International Journal of Educational Research, 89, 92-102. https://doi.org/10.1016/j.ijer.2017.10.002

Hoppe, F. (1930). Erfolg and Misserfold, Psychology, Forech, $14,1-62$

Johnson, L. (1995). A multidimensional analysis of the vocational aspirations of college students. Measurement and Evaluation in Counseling Psychology, 28(1), 25-44.

Malik R. S., (2015). Revisiting the occupational aspirations and destinations of anglo-australian and chineseaustralian high school students. Asia Pacific Journal of Education, 35(1), 27-39. https://doi.org/10.1080/02188791.2013.860010

Rojewski J. W., Lee I. H., Gregg N. \& Gemici S., (2012). Development patterns of occupational aspirations in adolescents with high-incidence disabilities. Exceptional Children, 78(2), 157-179. https://doi.org/10.1177/001440291207800202

Rojewski, J.W. (2005). Occupational Aspirations: Constructs, Meanings, and Application, in: S. D. Brown \& R. W. Lent (Eds.), Career development and counseling: Putting theory and research to work. Hoboken, NJ: John Wiley, 132.

Van Tuijl, C., \& Van der Molen, J. H. W. (2016). Study choice and career development in STEM fields: an overview and integration of the research. International journal of technology and design education, 26(2), 159-183. https://doi.org/10.1007/s10798-015-9308-1

Wu, Y.L., (2012). Examining the occupational aspirations of taiwanese aboriginal adolescents based on the developmental-contextual model of career development Asia Pacific Education Review, 13(4), 757-769. https://doi.org/10.1007/s12564-012-9234-9 


\section{Issues and Ideas in Education}

Chitkara University, Saraswati Kendra, SCO 160-161, Sector 9-C, Chandigarh, 160009, India

Volume 7, Issue 1

March 2019

ISSN 2320-7655

Copyright: [ 2019 Lilu Ram Jakhar] This is an Open Access article published in Issues and Ideas in Education (Issues Ideas Educ.) by Chitkara University Publications. It is published with a Creative Commons AttributionCC-BY 4.0 International License. This license permits unrestricted use, distribution, and reproduction in any medium, provided the original author and source are credited. 